\title{
OPTIMALISASI PEMANFAATAN APLIKASI SENAYAN LIBRARY MANAGEMENT SYSTEM (SLIMS) PADA PERPUSTAKAAN PERGURUAN TINGGI DI KOTA PEKANBARU
}

\author{
Fitriyana \\ Program Studi Ilmu Perpustakaan, Fakultas Ilmu Budaya, Universitas Lancang Kuning \\ E-mail : fitriyanaapl16@gmail.com \\ Triono Dul Hakim \\ Program Studi Ilmu Perpustakaan, Fakultas Ilmu Budaya, Universitas Lancang Kuning \\ E-mail: trio@unilak.ac.id \\ Hadira Latiar \\ Program Studi Ilmu Perpustakaan, Fakultas Ilmu Budaya, Universitas Lancang Kuning \\ E-mail: hadiralatiar6@gmail.com
}

Received: 12-06-2021

Revised: 20-06-2021

Accepted:25-06-2021

DOI: $10.24036 /$ ib.v2i2.180

\begin{abstract}
The purpose of this study was to determine the optimization of the utilization of the Senayan Library Management System (SLiMS) application in the library in Pekanbaru City. The method used in this research is qualitative. The sampling technique used is purposive sampling, which is sampling intentionally based on officers who are directly involved with the required sample requirements. The results of the study indicate that from several indicators that have been determined, the utilization of the SLiMS application cannot be said to be optimal because the features in the SLiMS application have not been fully utilized. Unilak Library UPT does not take advantage of two features, namely the Inventory feature and serial publication control feature, while the UMRI Library UPT has utilized all the features but there are still some sub-features that are not utilized.
\end{abstract}

Keywords: Optimization, Utilization of SLiMS, University Libraries

\begin{abstract}
Abstrak
Tujuan penelitian ini adalah untuk mengetahui optimalisasi pemanfaatan aplikasi Senayan Library Management System (SLiMS) pada perpustakaan di Kota Pekanbaru. Metode yang digunakan dalam penelitian ini adalah kualitatif. Teknik pengambilan sampel menggunakan Purposive Sampling yaitu pengambilan sampel secara sengaja berdasarkan petugas yang langsung terlibat dengan persyaratan sampel yang diperlukan. Hasil penelitian menunjukkan bahwa dari beberapa indikator yang telah ditetapkan maka pemanfaatan aplikasi SLiMS belum bisa dikatakan optimal karena fitur yang ada pada aplikasi SLiMS belum sepenuhnya dimanfaatkan. UPT Perpustakaan UNILAK tidak memanfaatkan dua fitur yaitu fitur Inventarisasi dan fitur kendali terbitan berseri, sementara UPT Perpustakaan UMRI telah memanfaatkan semua fitur namun masih ada beberapa sub fitur yang tidak dimanfaatkan.
\end{abstract}

Kata Kunci: Optimalisasi, Pemanfaatan SLiMS, Perpustakaan Perguruan Tinggi 
Published by Program Studi Perpustakaan dan IImu Informasi FBS Universitas Negeri Padang, Indonesia

\section{PENDAHULUAN}

Senayan Library Management System (SLiMS) atau yang sering disebut Senayan merupakan salah satu saftware untuk manajemen perpustakaan. Dalam buku penduan (Senayan Developers Community (SDC), 2017:11) yang dimaksud dengan Senayan Library Management System (SLiMS) adalah Open Source Software (OSS) berbasis web untuk memenuhi kebutuhan otomasi perpustakaan (library automation) skala kecil hingga skala besar. Aplikasi SLiMS dirilis dengan lisensi GPL sehingga menjamin kebebasan tiap pengguna untuk mendapatkan, memodifikasi, dan melakukan redistribusi, baik secara komersial ataupun tidak (Jaf, 2016:4).

Perpustakaan perguruan tinggi merupakan unsur penunjang perguruan tinggi, yang bersama-sama dengan unsur penunjang lainnya, berperan serta dalam melaksanakan tercapainya visi dan misi perguruan tingginya. Selain itu yang dimaksud dengan perguruan tinggi adalah universitas, institute, sekolah tinggi, akademi, politeknik, dan perguruan tinggi lain yang sederajat (Depdiknas:2014:11).

Dari hasil penelitian pada desember 2020, peneliti mendapat informasi bahwa penggunaan aplikasi SLiMS setiap universitas berbeda-beda, ketujuh universitas diketahui ada empat yang telah melakukan upgrade pada SLiMS versi terbaru bulian, beberapa di antaranya menggunakan software SLiMS mulai dari SLiMS cendaana hingga akasia. Penggunaan aplikasi SLiMS juga merupakan salah satu pilihan untuk membuat perkembangan pada perpustakaan, seperti dua perguruan tinggi yang akan menjadi lokasi dalam penelitian, yaitu Universitas Lancang Kuning dan Universitas Muhammadiyah Riau kota Pekanbaru Provinsi Riau.

Universitas Muhammadiyah Riau telah menggunakan aplikasi SLiMS sejak 2013 dan pada September 2020 telah melakukan upgrade perangkat lunak otomasinya ke Senayan Library Management System (SLiMS) versi Bulian. Hal ini bertujuan untuk menyesuaikan kebutuhan perangkat lunak yang memadai. Sama hal nya dengan Universitas Lancang Kuning yang telah melakukan upgrade perangkat lunak otomasi ke Senayan Library management System (SLiMS) versi bulian pada Agustus 2020.

Berdasarkan uraian di atas, peneliti tertarik mengetahui lebih lanjut dan mendalam tentang aplikasi Senayan Library Management System (SLiMS). Adapun rumusan masalah dalam penelitian ini adalah "Bagaimana Optimalisasi Pemanfaatan Aplikasi Senayan Library Management System (SLiMS) Pada 
Published by Program Studi Perpustakaan dan IImu Informasi

Perpustakaan Perguruan Tinggi di Kota Pekanbaru.

Berikut ini beberapa penelitian terdahulu yang peneliti jadikan sebagai rujukan penelitian, yaitu: Pertama, penelitian yang dilakukan oleh Dwiyantoro (Chevron \& Indonesia, n.d.) dengan judul "Evaluasi software aplikasi Senayan Library Management System (SLIMS) di lingkungan Universitas Lancang Kuning Pekanbaru menggunakanpendekatan ISO 9126 usability" Vol.2 No.1 Tahun 2020. Penelitian ini menggunakan metode deskriptif kuantitatif Dengan metode pengumpulan data observasi, penyebaran kuesioner, dan wawancara. Sampel dalam penelitian ini yaitu 7 responden yang berasal dari perpustakaan berbeda yang menggunakan aplikasi SLiMS. Analisis data dilakukan dengan menggunakan rumus persentase skala likert. Persamaan penelitian Dwiyantoro dengan penelitian yang peneliti lakukan adalah kedua objek penelitian yang membahas tentang aplikasi Senayan Library Management System (SLiMS. Sedangkan perbedaan pada penelitian Dwiyantoro dengan penelitian yang peneliti lakukan yaitu metode yang digunakan. Kedua, penelitian yang dilakukan oleh (Iswanto, Wince, \& Marleni, 2019). mahasiswa Institut Tinggi Agama Islam Negeri (IAIN) Curup dengan judul "Optimalisasi
Pemanfaatan Aplikasi SLiMS dalam Meningkatkan Kinerja Pustakawan di Perpustakaan Institut Tinggi Agama Islam Negeri Curup". Penelitian ini merupakan jurnal Tik Ilmue: Jurnal Ilmu Perpustakaan dan Informasi, Vol. 3, No. 2, 2019. Persamaan penelitian ini yaitu sama-sama membahas tentang optimalisasi pemanfaatan SLiMS, serta metode yang digunakan adalah metode pendekatan kualitatif. Sedangkan perbedaannya terdapat pada objek dan lokasi penelitian. Ketiga, penelitian yang dilakukan oleh (Rahmadhani \& Marlini, 2015) mahasiswa Universitas Negeri Padang dengan judul "Pemanfaatan Sofware SLiMS (Senayan Library Management System) di UPT Perpustakaan Kopertis Wilayah X (Sumatera Barat, Riau, Jambi, dan Kepulauan Riau)" Vol. 4 No. 1 September 2015. Penelitian ini menggunakan metode deskriptif, yaitu menguraikan temuan atau data penelitian dengan pengumpulan data melalui observasi dan mewawancarai pustakawan UPT Perpustakaan Kopertis Wilayah X. Persamaan penelitian yang dilakukan Dahlia Rahmadhani dengan penelitian yang peneliti lakukan adalah untuk mengetahui pemanfaatan SLiMS pada sebuah Perpustakaan, hanya terdapat perbedaan dari segi bahasa dan makna dengan menganalisis lebih luas tentang 
Published by Program Studi Perpustakaan dan IImu Informasi

FBS Universitas Negeri Padang, Indonesia

pengoptimalan aplikasi SLiMS, sedangkan

Perbedaan penelitian yang dilakukan Dahlia

Rahmadhani dengan penelitian peneliti lakukan terletak pada waktu dan tempat penelitian.

\section{METODE}

Peneliti memfokuskan penelitian pada dua Perguruan Tinggi yang ada di Kota Pekanbaru, yaitu Universitas Lancang Kuning dan Universitas Muhammadiyah Riau. Waktu Penelitian dilaksanakan pada bulan November 2020-Januari 2021. Metode yang peneliti gunakan dalam penelitian ini adalah deskriptif kamparatif dengan pendekatan kualititatif. Teknik pengumpulan data berupa observasi, wawancara dan dokumentasi. Sampel dalam penelitian ini peneliti ambil berdasarkan petugas yang langsung terlibat dengan objek penelitian sebanyak 12 orang.

\section{HASIL DAN PEMBAHASAN}

Hasil penelitian ini telah dilakukan mulai dari bulan November 2020-Januari 2021. Untuk menjawab rumusan masalah pada bab 1 yaitu Bagaimana Optimalisasi Pemanfaatan Aplikasi Senayan Library Management System (SLiMS) Pada Perpustakaan Perguruan Tinggi di Kota Pekanbaru, maka peneliti melakukan pengamatan langsung serta wawancarai sebanyak 12 informan yang terdiri dari Kepala Perpustakaan, Pustakawan serta pemustaka dimasing-masing Perpustakaan yang menjadi lokasi penelitian.

Dari hasil penelitian yang telah peneliti lakukan pada perpustakaan perguran tinggi di kota Pekanbaru yaitu UPT Perpustakaan Universitas Muhammdiyah Riau dan UPT Perpustakaan Universitas Lancang Kuning. Peneliti mendapat informasi bahwa, UPT Perpustakaan Umri telah menggunakan aplikasi SLiMS sejak tahun 2013, versi yang digunakan adalah SLiMS stable 3, pada tahun 2015 dilakukan upgrade SLiMS versi 5, terakhir september 2020 dilakukan lagi upgrade pada versi terbaru bulian. Sementara pada UPT Perpustakaan Unilak penggunaan SLiMS telah diterapkan sejak tahun 2013 dengan versi stable 3. Pada tahun 2015 UPT Perpustakaan Unilak melakukan upgrade SLiMS 7, dua tahun pemakaian UPT Perpustakaan Unilak melakukan upgrade lagi pada SLiMS 8 dan pada agustus 2020 telah melakukan upgrade pada versi terbaru bulian.

Adapun untuk mengetahui bagaimana optimalisasi pemanfaatan aplikasi Senayan Library Management System (SLiMS) pada Perpustakaan Perguruan Tinggi di Kota Pekanbaru yaitu UPT Perpustakaan UNILAK 
Published by Program Studi Perpustakaan dan Ilmu Informasi FBS Universitas Negeri Padang, Indonesia

dan UPT Perpustakaan UMRI, maka peneliti melakukan wawancara dengan mengajukan beberapa pertanyaan, berikut hasil yang peneliti dapat.

\section{OPAC}

Fitur OPAC menjadi alternatif bagi pemustaka untuk menemukan koleksi yang ada pada perpustakaan. Fitur OPAC merupakan sebuah wadah yang disediakan dalam temu kembali koleksi. Pemahaman pemustaka pada kedua perpustakaan berbeda-beda. Seperti pada UPT Perpustakaan UMRI, beberapa pemustaka ada yang memilih langsung menuju ke rak, sementara mereka masih bingung buku yang dicari berada pada kelas berapa. Berbeda dengan UPT Perpustakaan UNILAK, selalu terjadi gangguan pada komputer yang disediakan sehingga pemustaka berusaha mencari koleksi yang diinginkan atau langsung bertanya pada pustakawan.

\section{Bibliografi}

Fitur yang ada pada aplikasi SLiMS ini digunakan untuk melakukan penginputan koleksi yang ada di perpustakaan, menu atau fitur ini juga bisa mencetak barcode, nomor panggil serta kartu katalog. Berbagai koleksi yang dimasukkan dalam bibliografi juga bisa langsung ditemu kembali pemustaka melalui OPAC. Fitur bibliografi juga memiliki sub-sub fitur dan tidak semua sub fitur yang ada dimanfaatkan karena menurut informan setiap fitur dan sub fitur dijalankan dan dimanfaatkan menyesuaikan kebutuhan dan kebijakan dari perpustakaan. Untuk mengetahui lebih jelas peneliti memberi beberapa pertanyaan tentang fitur bibliografi.

\section{Sirkulasi}

Fitur sirkulasi merupakan salah satu fitur yang dianggap sangat memiliki pengaruh besar pada perpustakaan terkhusus memberi kemudahan bagi pustakawan dan pemustaka, hal ini dikarenakan fitur sirkulasi bisa mempercepat pemustaka untuk melakukan peminjaman, pengembalian serta perpanjangan buku, berbeda sekali jika peminjaman dan pengembalian buku dilakukan secara manual. Selain harus menunggu lama karena antrian, pustakawan juga akan kewalahan untuk mengatur keadaan yang terjadi.

\section{Keanggotaan}

Fitur keanggotaan dimanfaatkan untuk mengatur jenis keanggotan, seperti mahasiswa, karyawan dan dosen. Dari beberapa jenis keanggotaan ini masingmasing memiliki perbedaan hak dalam meminjam buku yang ada pada perpustakaan. contoh, jika mahasiswa 
Published by Program Studi Perpustakaan dan Ilmu Informasi FBS Universitas Negeri Padang, Indonesia

hanya bisa meminjam buku dalam jangka waktu seminggu sementara dosen memiliki tenggang waktu satu bulan. Berbeda dengan UPT Perpustakaan UMRI, pihak perpustakaan membuat kebijakan bahwa batas peminjaman buku untuk mahasiswa berlangsung empat belas hari atau dua minggu, sementara dosen bisa meminjam selama tiga bulan.

\section{Inventarisasi}

Inventarisasi berarti mendata buku-buku yang ada pada perpustakaan. Di Perpustakaan fitur inventarisasi digunakan untuk melakukan stock opname, kegiatan ini dilakukan dengan tujuan membuat perbandingan jumlah koleksi berdasarkan yang sudah terdata dengan koleksi yang ada pada rak. Hasil wawancara yang dilakukan peneliti dengan informan tentang optimalisasi pemanfaatan fitur inventarisasi pada perpustakaan. Berhubungan dengan fitur ini wawancara hanya peneliti lakukan dengan informan 1 sampai dengan 3 karena informan 4 sampai dengan 5 menyatakan bahwa fitur inventarisasi tidak digunakan pada UPT perpustakaan Unilak. Alasan tidak digunakan fitur tesebut karena sejak awal perpustakaan melakukan inventaris secara manual dan selanjutnya mengikuti daftar inventaris yang sudah ada.

\section{Kendali Terbitan Berseri}

Fitur ini dimanfaatkan untuk mengatur jenis koleksi terbitan berkala atau dari perpustakaan melanggan majalah, koran dan lainnya. Pada UPT Perpustakaan UMRI fitur ini digunakan sesuai kebutuhan, namun pada UPT Perpustakaan UNILAK, fitur kendali terbitan berkala tidak dimanfaatkan karena tidak ada majalah atau jenis terbitan berkala lainnya yang dilanggan.

\section{Pelaporan}

Fitur pelaporan sangat membantu merekap berbagai laporan yang dibutuhkan dalam perpustakaan. Jika pada perpustakaan konvensional semua hal dikerjakan secara manual, namun dengan adanya fitur pelaporan ini tentu memberi kemudahan khususnya bagi pustakawan untuk membuat berbagai jenis laporan yang diinginkan. Pustakawan tinggal memilih sub-sub fitur yang tersedia pada fitur pelaporan, contohnya laporan denda keterlambatan, di fitur pelporan semua sudah terdata dengan baik, baik laporan perminggu, perbulan hingga pertahun.

UPT Perpustakaan Umri telah memanfaatkan fitur pelaporan dengan sangat baik, wawancara menghasilkan bahwa semua jenis laporan yang diinginkan bisa dibuat pada fitur ini. Berdasarkan hasil 


\section{Info Bibliotheca}

Published by Program Studi Perpustakaan dan IImu Informasi FBS Universitas Negeri Padang, Indonesia

pengamatan langsung, peneliti juga melihat bahwa fitur pelaporan sangat membantu pustakwan dalam membuat berbagai jenis laporan yang diinginkan oleh pimpinan. Sudah sangat jelas, fitur ini berjalan optimal serta pemahaman dari pustakawan juga sangat baik.

Dari keseluruhan hasil di atas, maka peneliti menarik kesimpulan bahwa pemanfaatan aplikasi Senayan Libarary Management System (SLiMS) pada perpustakaan perguruan tinggi yaitu Universitas Lancang Kuning dan Universitas Muhammadiyah Riau belum dikatakan optimal karena kedua perpustakaan yang menjadi lokasi penelitian belum memanfaatkan semua fitur dengan baik. Beberapa fitur atau menu besar yang disediakan, ada yang sama sekali tidak dimanfaatkan di Universitas Lancang kuning yaitu fitur Inventarisasi dan Kendali Terbitan Berseri. Berikut tabel pemanfaatan fitur-fitur yang ada pada aplikasi SLiMS di dua Perpustakaan perguruan tinggi:

Tabel 1 Pemanfaatan Fitur SLiMS

\begin{tabular}{|l|c|c|c|c|}
\hline \multirow{3}{*}{ Nama } & \multicolumn{2}{|c|}{$\begin{array}{c}\text { UPT } \\
\text { Perpustakaan } \\
\text { UNILAK }\end{array}$} & \multicolumn{2}{c|}{$\begin{array}{c}\text { UPT } \\
\text { Perpustakaan } \\
\text { UMRI }\end{array}$} \\
\cline { 2 - 5 } & $\begin{array}{c}\text { Sudah } \\
\text { Dimanf } \\
\text { aatkan }\end{array}$ & $\begin{array}{c}\text { Belum } \\
\text { Diman } \\
\text { faatka } \\
\mathrm{n}\end{array}$ & $\begin{array}{c}\text { Sudah } \\
\text { Diman } \\
\text { faatka } \\
\mathrm{n}\end{array}$ & $\begin{array}{c}\text { Belum } \\
\text { Diman } \\
\text { faatka } \\
\mathrm{n}\end{array}$ \\
\hline OPAC & $\sqrt{ }$ & & $\sqrt{ }$ & \\
\hline $\begin{array}{l}\text { Bibliog } \\
\text { rafi }\end{array}$ & $\sqrt{ }$ & & $\sqrt{ }$ & \\
\hline
\end{tabular}

\begin{tabular}{|l|l|l|l|l|}
\hline $\begin{array}{l}\text { Inventa } \\
\text { risasi }\end{array}$ & $\sqrt{ }$ & $\sqrt{ }$ & \\
\hline $\begin{array}{l}\text { Sirkula } \\
\text { si }\end{array}$ & $\sqrt{ }$ & & $\sqrt{ }$ & \\
\hline $\begin{array}{l}\text { Keangg } \\
\text { otaan }\end{array}$ & $\sqrt{ }$ & & $\sqrt{ }$ & \\
\hline $\begin{array}{l}\text { Kendali } \\
\text { Terbita } \\
\text { n } \\
\text { Berkala }\end{array}$ & & $\sqrt{ }$ & $\sqrt{ }$ & \\
\hline Sistem & $\sqrt{ }$ & & $\sqrt{ }$ & \\
\hline $\begin{array}{l}\text { Pelapor } \\
\text { an }\end{array}$ & $\sqrt{ }$ & & $\sqrt{ }$ & \\
\hline
\end{tabular}

Sumber:Data Penelitian 2021

Tabel di atas menunjukkan bahwa keseluruhan dari fitur yang ada di aplikasi SLiMS sudah dimanfaatkan oleh kedua perpustakaan perguruan tinggi, namun pada UPT Perpustakaan UNILAK ada dua fitur yang tidak dimanfaatkan yaitu fitur inventarisasi dan kendali terbitan berkala. Pemanfaatan fitur yang ada pada aplikasi SLiMS ini disesuaikan berdasarkan kebutuhan pada perpustakaan.

\section{PENUTUP}

\section{Simpulan}

Berdasarkan hasil penelitian yang peneliti lakukan tentang optimalisasi pemanfanfaatan aplikasi Senayan Library Management System (SLiMS) pada perpustakaan pergurua tinggi di kota Pekanbaru, dari kedua perguruan tinggi yang menjadi lokasi penelitian yaitu Universitas Muhammdiyah Riau dan Universitas Lancang Kuning, maka dapat 
Published by Program Studi Perpustakaan dan Ilmu Informasi FBS Universitas Negeri Padang, Indonesia

ditarik kesimpulan bahwa fitur yang menjadi indikator dalam penelitian telah dimanfaatkan oleh kedua Universitas namun dari ketujuh fitur tersebut, ada dua fitur yang tidak dimanfaatkan pada Universitas Lancang Kuning yaitu fitur Inventarisasi dan Kendali terbitan Berseri. Sedangkan fitur Inventarisasi pada Universitas Muhammadiayah Riau digunakan untuk memudahkan melakukan stock opname. Sementara fitur Kendali Terbitan Berseri dimanfaatkan karena memang UPT Perpustakaan UMRI memiliki langganan koran tribun serta majalah suara Muhammadiyah. Pemanfaatan fitur yang ada pada aplikasi SLiMS disesuaikan berdasarka kebutuhan dan kebijakan pada kedua Perpustakaan.

\section{Saran}

Mengacu pada kesimpulan di atas serta hasil pengamatan yang telah peneliti lakukan pada perpustakaan perguruan tinggi di kota Pekanbaru yaitu Universitas Muhammadiyah Riau dan Universitas Lancang Kuning, maka ada beberapa saran yang ingin peneliti sampaikan untuk menjadi tolak ukur sehingga menjadi lebih baik kedepannya, antara lain:

1. Untuk mengatasi pemahaman pemustaka dalam menggunakan fitur OPAC, perlu dilakukan pendidikan pemakai dengan lebih baik dan teliti agar penyampaian materi bisa diterima dengan baik, hal lain yang bisa diterapkan seperti menyediakan panduan penggunaan OPAC, Panduan penelusuran dan lainnya, dengan tujuan pemustaka lebih paham memanfaatkan fitur tersebut.

2. Aplikasi SLiMS menyediakan sebuah komunitas untuk pengguna melakukan diskusi terkait permasalahan yang ditemukan, alangkah baiknya semua pustakawan bisa bergabung sehingga pengetahuan terhadap aplikasi SLiMS bisa didapatkan dari berbagai diskusi tersebut.

3. Sarana yang menjadi kebutuhan pemustaka seperti komputer untuk penelusuran opac, hendaknya disediakan dengan kualitas yang lebih baik serta jumlah yang lebih banyak

\section{DAFTAR PUSTAKA}

Agustinova, D. E. (2015). Memahami Metode Penelitian Kualitatif Teori \& Praktek. Yogyakarta: Calpulis.

Arikunto, S. (2014). Prosedur Penelitian: Suatu Pendekatan Praktik. Jakarta: Rineka Cipta.

Chevron, P. T., \& Indonesia, P. (n.d.). Evaluasi software aplikasi Senayan Library Management System ( SLIMS ) di lingkungan Universitas Lancang Kuning Pekanbaru menggunakan pendekatan ISO 9126 usability. 


\section{Info Bibliotheca}

Published by Program Studi Perpustakaan dan Ilmu Informasi

FBS Universitas Negeri Padang, Indonesia

21-31.

Iswanto, R., Wince, E., \& Marleni, M. (2019). Optimalisasi Pemanfaatan Aplikasi SliMS dalam Meningkatkan Kinerja Pustakawan pada Perpustakaan Institut Agama Islam Negeri Curup. Tik Ilmeu: Jurnal Ilmu Perpustakaan Dan Informasi, 3(2), 159. https://doi.org/10.29240/tik.v3 i2.1132

Jaf, H. H. (2016). Tips mudah membangun perpustakaan dengan SLiMS (Senayan Library Management System). Yogyakarta: Lembaga Ladang Kata.

Mulyadi. (2016). Pengelolaan Otomasi Perpustakaan Berbasis Senayan Library Management System (SLiMS). Jakarta: Rajawali Pers.

Norlice Vera Potoboda, Servi Stevi Sumendap, \& Y. P. (2016). Membangun Sistem Otomasi Perpustakaan Sebagai Upaya Mempertahankan Eksistensi

Perpustakaan (Studi pada Badan Perpustakaan Arsip dan Dokumentasi

Provinsi Sulawesi Utara). E-Journal "Acta Diurna," $V(5)$. Retrieved from https://ejournal.unsrat.ac.id/ind ex.php/actadiurnakomunikasi/a rticle/view/13545

Perpustakaan Perguruan Tinggi: Buku Pedoman. (2004). Departemen Pendidikan Nasional RI Direktorat Jendral Pendidikan Tinggi.

Rahmadhani, D., \& Marlini. (2015). Pemanfaatan Software SLiMS (Senayan Library Management System) Di UPT Perpustakaan
Kopertis Wilayah X (Sumatera Barat, Riau, Jambi, Dan Kepulauan Riau). Jurnal IImu Informasi Perpustakaan Dan Kearsipan, 4(1, September 2015), 192-203.

Senayan Developers Community (SDC). (2017). Panduan Penggunaan Senayan Library management System. 116. Retrieved from https://slims.web.id/goslims/? wpdmpro=slims4dummiespanduan-penggunaan-slims

Sugiyono. (2017). Metode Penelitian Kualitatif (Untuk penelitian yang bersifat: eksploratif, enterpretif, interaktif dan konstruktif)S. Bandung: Alfabeta.

Warpani, S. (2014). Optimalisasi. Retrieved November 25, 2020, from Kompasiana website: https://www.kompasiana.com/s warpani/5529b72bf17e61b81d d623b5/optimalisasi 
